\title{
Generalized Edema Resulting from Mixed Intestinal Infection by Entamoebia Histolytica and E. Coli in a Nigerian Female Adolescent: A Case Report
}

\author{
Ajite Adebukola ${ }^{1,2 *}$, Oluwayemi Oludare ${ }^{1,2}$ and Fatunla Odunayo ${ }^{2}$ \\ ${ }^{1}$ Department of Paediatrics, Ekiti State University, Nigeria \\ ${ }^{2}$ Department of Paediatrics, Ekiti State University Teaching Hospital, Nigeria
}

Submission: March 15, 2021; Published: April 08, 2021

*Corresponding author: Ajite Adebukola, Consultant Paediatrician, Department of Paediatrics, Ekiti State University, Ado Ekiti, Nigeria

Abstract

Amoebiasis, a clinical condition caused by Entamoeba histolytica does not usually present with generalized oedema known as anarsarca. We present a case of an adolescent female Nigerian who was admitted on account of chronic diarrhea and anarsarca in a tertiary hospital, Southwest Nigeria. There was no proteinuria. She however had cyst of $E$. histolytica and growth of $E$. coli in her stool; she also had $E$. coli isolated in her urine. She had hypoproteinaemia $(35.2 \mathrm{~g} / \mathrm{L})$ and hypoalbuminaemia $(21.3 \mathrm{~g} / \mathrm{L})$ as well as hypokalemia $(2.97 \mathrm{mmol} / \mathrm{L})$. Symptoms resolved and biochemical parameters normalized following treatment with Nitrofurantoin, Tinidazole and Ciprofloxacin. A mixed infection of Entamoeba histolytica and Escherichia coli bacteria may be responsible for the worse clinical manifestations of Amoebiasis

Keywords: Amoebiasis; Chronic diarrhea; Hypoproteinaemia; Anasarca

\section{Introduction}

Amoebiasis, caused by the protozoan Entamoeba histolytica is an infection that frequently manifests clinically with symptoms of abdominal pain, diarrhoea, dysentery and weight loss [1,2]. Some patients may be asymptomatic while some may have extraintestinal symptoms of liver abscess, cerebral abscess and even pneumonia [1,2]. There are reports of hypoproteinaemia and pedal oedema associated with amoebiasis [3,4], however, none have reported generalized oedema also known as anasarca. There is evidence to suggest that a mixed infection of Entamoeba histolytica and Escherichia coli bacteria may result in worse clinical manifestations of Amoebiasis [5,6]. We report a case of mixed $E$. histolytica and $E$. coli infection in an adolescent presenting with anasarca from hypoproteinaemia in a tertiary hospital, Southwest Nigeria.

\section{Case Report}

A 15-year-old female student of a tertiary institution was admitted at the emergency unit of the Ekiti State University Teaching Hospital, Ado-Ekiti in May 2020 with a ten-month history of recurrent passage of non-bloody, loose stools and recurrent generalized body swelling, and a seven-month history of amenorrhoea.

She had up to seven episodes of non-bloody, loose stools per day with an estimated volume of $50-100 \mathrm{ml}$ per episode, associated with tenesmus and lower abdominal pain. The index series of loose stools had occurred for 3 consecutive months. There was no history of fever, vomiting, significant weight loss or jaundice. She denied patronizing food vendors and claimed that her meals had always been prepared by her mother. None of the members of her household had similar symptoms and she belonged to the middle social class. She first noticed facial swelling at the periorbital areas, which progressively involved her lower limbs and abdomen, although her upper limbs were spared of oedema. The facial swelling was reportedly worse in the mornings. There was no history of passage of frothy urine, dysuria or change in urine colour, frequency and volume.

About three months after the outset of symptoms, she noticed a cessation of her menstruation. She had attained menarche at 14 years, barely a couple of months prior her illness, and menstruated for 3 days in a 28-day cycle. There was no undue hair growth or 
hair loss, no voice change or incessant headaches. There was no history of palpitations, heat intolerance or neck swelling. She had initially presented at a health facility where she was given several medications, including metronidazole, to no avail.

She looked weak at presentation, had normal hair colour and texture, she was neither pale nor icteric. She had bilateral periorbital oedema and bilateral pitting oedema on her lower limbs up to the knees. She weighed $55 \mathrm{~kg}$ and had a normal body mass index (BMI) for her age and sex of $21 \mathrm{~kg} / \mathrm{m}^{2}$. She had a sexual maturity rating (SMR) of 3 . Abdominal examination findings included slight distension with a flat umbilicus but no obvious peripheral veins or visible peristaltic movement. She had vague abdominal tenderness but no palpable mass. Ascites was however demonstrable by shifting dullness and confirmed on ultrasonography. Her bowel sounds were present and normal. All other examination findings were normal.

There was no proteinuria and other parameters on urinalysis were essentially normal. She however had cyst of E. histolytica and growth of E. coli in her stool; she also had E. coli isolated in her urine. The bacteria isolate in both her stool and urine was sensitive to only Nitrofurantoin, while her mother's stool and urine had no organism. The patient had hypoproteinaemia $(35.2 \mathrm{~g} / \mathrm{L})$ and hypoalbuminaemia $(21.3 \mathrm{~g} / \mathrm{L})$ as well as hypokalemia $(2.97 \mathrm{mmol} / \mathrm{L})$; other values on her liver function and renal function tests were normal. Her Full Blood Count (FBC) results revealed packed red cell volume of $30 \%$, leukocytosis with significant neutrophilia, she also had trophozoites of Plasmodium falciparum on blood film. Her haemoglobin genotype was AA. Serum pregnancy test and serology tests for Hepatitis B, C and Human Immunodeficiency Virus (HIV) were all negative. Abdominal scan showed ascites with normal intra-abdominal organs.

She was treated with Nitrofurantoin, Tinidazole and Ciprofloxacin, given amino acid supplements, oral potassium and was commenced on high protein diet. She was also treated for malaria and counseled on food and perianal hygiene. The generalized oedema significantly resolved within a week on admission and she was discharged home on the $8^{\text {th }}$ day. On follow up visit at the clinic a week after discharge, she had no evidence of oedema, serum protein $(42.1 \mathrm{~g} / \mathrm{L})$ and albumin $(26.2 \mathrm{~g} / \mathrm{L})$ had significantly improved. The serum potassium was $3.37 \mathrm{mmol} / \mathrm{l}$. She also resumed menstruation within a month of commencing treatment. A repeat stool m/c/s showed a well-formed stool, no blood or pus was seen and there were no ova or cyst of parasite seen. There was no significant growth of organism in the stool.

\section{Discussion}

Anasarca commonly results from increased capillary pressure or permeability, reduced plasma oncotic pressure [7]. Oedema associated with reduced oncotic pressure is often caused by hypoproteinaemia [7]. Nephrotic syndrome is a common differential of anasarca characterized by massive proteinuria and hypoproteinaemia $[8,9]$. In this case report, the absence of proteinuria excluded the diagnosis of nephrotic syndrome despite anasarca and hypoproteinaemia. Howbeit, this case report highlights that the absence of other manifestations of hypoproteinaemia such as low BMI or frail hair [10], especially in the absence of proteinuria do not exclude hypoproteinaemia.

The patient in this case report did not present with bloody stool (dysentery), which probably reduced its suspicion at the early stage, moreover, the chronic diarrhoea did not abate with metronidazole prescribed to the patient prior to presentation in our facility. Metronidazole is one of the recommended drugs for protozoans such as Entamoeba as it is known to cause DNA breakage and cell death in susceptible organisms [11,12]. Nonetheless, Shaulov et al. [6] in 2018 submitted that E. coli protects E. histolytica from oxidative stress, this is a plausible reason why the patient in this case report had no symptom relief with metronidazole at the initial stage.

In a similar vein, this patient also presented with significant hypoproteinaemia, leading to anasarca, this is a rare presentation of amoebiasis. A mixed infection with E. coli may also explain this as was previously documented by Galván-Moroyoqui et al. [5]. The authors reported that $E$. coli potentiated the virulence of $E$. histolytica, characterized by increased expression of cysteine proteinases and intense epithelial cell damage in animal models [5], therefore, protein may leak into the intestinal lumen resulting in significant loss in diarrhoeal stool along with other electrolytes especially potassium.

Mixed infections of E. histolytica and E.coli may be common in endemic regions such as reported in this case report; both infections have faeco-oral transmission route [12,13]. Food hygiene, regular hand washing and other hygienic practices especially among food handlers will reasonably contain these diseases [14]. It may also be necessary to exclude these mixed infections by requesting for stool microscopy and culture from patients who have chronic diarrhoea for holistic management. As observed in this case report, a combination of antibiotics to address both infections is cardinal to quick and complete recovery.

E. coli is a usual cause of urinary tract infection as observed in this case report, which may have resulted from intestinal colonization and facilitated by poor perianal hygiene [15]. There is a need to emphasize this aspect of health education in school curricula to forestall this among girls. The secondary amenorrhoea observed in this patient is expected, as it has been reported that adolescent females may have amenorrhoea after about 3-6 months of regular menstruation, and menstruation may not resume for up to 2 years $[16,17]$. Besides, chronic illnesses including chronic diarrhoea is a known cause of secondary amenorrhoea [17]. 


\section{Conclusion}

Mixed E. histolytica and E. coli infection may have unusual clinical manifestations like significant hypoproteinaemia and generalized edema. Both infections need to be treated to ensure optimal management.

\section{References}

1. Haque R, Huston CD, Hughes M, Houpt E, Petri WA (2003) Amebiasis. N Engl J Med 348(16): 1565-1573.

2. Kantor M, Abrantes A, Estevez A, Schiller A, Torrent J, et al. (2018) Entamoeba Histolytica: Updates in Clinical Manifestation, Pathogenesis, and Vaccine Development. Canadian Journal of Gastroenterology and Hepatology 2018: e4601420.

3. Jaiswal SS, Mehra R, Pattnaik MR (2015) Amoeboma—Lest We Forget!!! Indian J Surg 77(Suppl 1): 190-192.

4. Babić E, Bevanda M, Mimica M, Karin M, Volarić M, et al. (2016) Prevalence of amebiasis in inflammatory bowel disease in University Clinical Hospital Mostar. Springerplus 5(1): 1586.

5. Moroyoqui JMG, Robles M del CD, Franco E, Meza I (2008) The Interplay between Entamoeba and Enteropathogenic Bacteria Modulates Epithelial Cell Damage. PLoS Negl Trop Dis 2(7): e266.

6. Shaulov Y, Shimokawa C, Geffen MT, Nagaraja S, Methling K, et al (2018) Escherichia coli mediated resistance of Entamoebahistolytica to oxidative stress is triggered by oxaloacetate. PLoS Pathog 14(10): e1007295.

7. Kattula SRST, Avula A, Baradhi KM (2020) Anasarca. In: Stat Pearls Treasure Island (FL). StatPearls Publishing.
8. Olowu WA, Ademola A, Ajite AB, Saad YM (2017) Childhood nephrotic syndrome in tropical Africa: then and now. Paediatr Int Child Health 37(4): 259-268.

9. Anigilaje EA, Fashie AP, Ochi C (2019) Childhood nephrotic syndrome at the University of Abuja Teaching Hospital, Abuja, Nigeria: a preliminary report supports high steroid responsiveness. Sudan J Paediatr 19(2): 126-139.

10. Soeters PB, Wolfe RR, Shenkin A (2019) Hypoalbuminemia: Pathogenesis and Clinical Significance. J Parenter Enter Nutr 43(2): 181-193.

11. Weir CB, Le JK. Metronidazole (2020) In: StatPearls. Treasure Island (FL). StatPearls Publishing.

12. Dhawan VK (2019) Amebiasis Medication. Medscape.

13. Ameer MA, Wasey A, Salen P. Escherichia Coli (E Coli 0157 H7). In: StatPearls. 2020. Treasure Island (FL). StatPearls Publishing.

14. Singh P, Galhotra A (2014) Water, Amoebiasis and Public Health. In: Water and Health 2014: 169-177.

15. Schlager TA, Hendley JO, Bell AL, Whittam TS (2002) Clonal Diversity of Escherichia coli Colonizing Stools and Urinary Tracts of Young Girls. Infect Immun 70(3): 1225-1229.

16. Greydanus DE, Sorrel S, Omar HA (2012) 17. Menstrual disorders in the adolescent female. In: Greydanus DE, Patel DR, Omar HA, Feucht C, Merrick J (Eds.), Adolescent Medicine: Pharmacotherapeutics in General, Mental and Sexual Health. Berlin, Boston. De Gruyter.

17. Greydanus DE, Sorrel S, Omar HA, Dodich CB (2012) Adolescent female menstrual disorders. Int J Child Adolesc Health 5(4): 357-378.

Your next submission with Juniper Publishers will reach you the below assets

- Quality Editorial service

- Swift Peer Review

- Reprints availability

- E-prints Service

- Manuscript Podcast for convenient understanding

- Global attainment for your research

- Manuscript accessibility in different formats ( Pdf, E-pub, Full Text, Audio)

- Unceasing customer service

Track the below URL for one-step submission

https://juniperpublishers.com/online-submission.php 